\title{
ACRL Board of Directors' actions, July 1996
}

\section{Highlights of the ACRL Board's Annual Conference meetings}

D uring the 1996 ALA Annual Conference in
New York City the ACRL Board of Directors took the following actions:

\section{ACRL governance}

Voted to approve the new Professional Development Committee charge: to promote the professional competence, growth, and development of academic librarians through the education process.

\section{Voted to establish two separate committees} to carry out the division's appointment and nomination functions.

Voted to approve the revised constitution. [The Board will address and make any changes deemed necessary to the revised constitution, then vote on any subsequent changes at the 1997 Midwinter Meeting in Washington, D.C. If the changes are approved a second time, the constitution, along with any changes to the bylaws, will be placed on the spring 1997 ballot for a membership vote.]

Voted to approve appointing, for a one-year term, Maxine Reneker as the new ACRL Councilor to fill the position vacated by Lee Hisle, who was elected ACRL vice-president/president-elect in the 1996 ALA elections.

Voted to approve the ECISS Bylaws change.

Voted to approve criteria for making appointments to the New Publications Advisory Committee.

Voted to approve a resolution honoring Gloriana St. Clair upon completion of six years as editor of CERL.
Voted to approve the revised charge for the Image Enhancement Committee with language added to include work in the area of recruitment to the profession and the committee's liaison role to the ALA Recruitment Assembly.

Voted to approve the committee's name change from Image Enhancement to Professional Enhancement.

Voted to approve the revised charge for the International Relations Committee.

Voted to establish a task force to develop a proposal on providing funding support to ACRL units other than chapters.

\section{ACRL Strategic Plan}

Voted to approve the policies for implementation of the Strategic Plan and a process for making changes to the plan.

Voted to approve the modification to the Strategic Plan recommended by the Publications Committee that adds Direction 1.5 under Goal 1: "1.5. ACRL will promote study, research, and publications relevant to academic and research librarianship."

Voted to approve the Criteria for Measuring Success of the Strategic Plan, requested that the document be publicized to the membership of the association, that input be sought, and that ACRL move forward with an implementation plan.

\section{Chapters}

Voted to approve appointment of a task force consisting of members from the ACRL Board and the Budget and Finance Committee, and four members from Chapters Council to revise the existing ACRL Chapter Relations and Benefits documents to identify incentives for rewarding chapters and involving ACRL national members in local activities. 


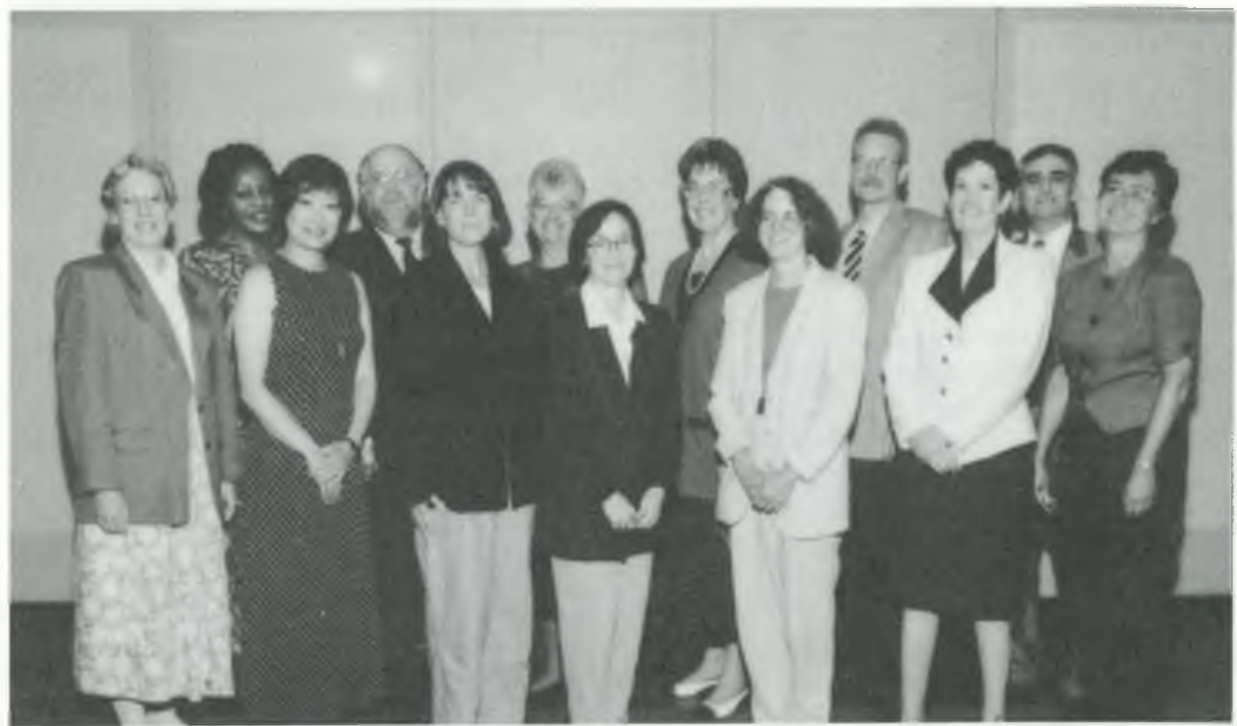

ACRL Board 1995-96 (I to r): Helen H. Spalding, Althea Jenkins, Linda Muroi, Bernard Fradkin, Frances Maloy, Mary Reichel, Victoria Montavon, Patricia Senn Breivik, Carol Pfeiffer, W. Lee Hisle, Jill Fatzer, William Miller, and Susan Martin.

\section{Professional development}

Voted to approve Detroit as the site for the 1999 ACRL National Conference, April 9-12, 1999.

Voted to approve ten program proposals from ACRL units for 1997 ALA Annual Conference Programs.

\section{Financial actions}

Voted to approve the Purpose Statement for use of the ACRL Endowment income.

Voted to approve the recommended increases in basic services funding to sections for 1997 and to provide sections with two sets of mailing labels annually.

Voted to approve allocating the unallocated FY1997 initiative funds to implement "Training the Trainer" programs at the 1997 Midwinter Meeting and Annual Conference as a followup to the 1996 Leadership Program.

Voted upon recommendation of the Budget and Finance Committee to approve the 1997 ACRL Budget that will be amended to reflect the increases in section funding, and which is projected to realize a fund balance due to the National Conference projected revenues, and does not include a transfer to the ACRL endowment; and voted to approve the 1997 Cboice budget as a deficit budget that realizes an operating fund balance that includes the mandated operating reserve and does not include a transfer to the Choice endowment.

\section{Grants}

Voted to approve the Community Information Organization grant proposal and give staff and committee members authority to revise the proposal as needed to suit potential funders and work with the ALA Development Office to secure funding.

Voted to approve the EASI grant proposal and give staff and committee members authority to revise the proposal as needed to suit potential funders and work with the ALA Development Office to secure funding.

\section{Reports}

Voted to accept the Paraprofessionals and Nonlibrarians in Academic Libraries Task Force report and commended the group for its work. Votes on individual items in the report that needed to be addressed are as follows:

1) Voted to approve offering an award to ACRL chapters to target paraprofessionals and their concerns in their programs, literature, and 
membership drives as part of the funding in the 1998 Initiative Fund.

2) Voted to approve that the 1999 National Conference Executive Committee, when preparing the budget, consider "first time" discounts on conference registration at ACRL National Conferences to encourage the participation of paraprofessionals at ACRL National Conferences.

3) Voted to table the following two recommendations and the rest of the Paraprofessional Task Force report to be included on a later Board agenda, conference call, or the fall meeting:

a) Provide travel scholarships to chapters that offer the greatest number of continuing education programs for professionals.

b) Host an annual meeting (perhaps at ALA Midwinter) of the ACRL Paraprofessional Task Force, COLT, and the ALA Support Staff Interests Roundtable and set an overall strategies agenda with definite responsibilities.

\section{Voted to accept the Standards Study Task}

Force report and commend the group for its work; and voted to establish a short-term task force to develop:

1) a framework for assessing libraries in terms of desired campus outcomes;
2) prototypes for such assessments; and

3) a process for implementation of an assessment with timeframes for completion.

It was also agreed that the task force would give attention to work done previously by ACRL members on output measures.

\section{Voted to approve ACRL's participation in} the Institutional Priorities and Faculty Reward Projects and establish a task force consisting of five members with representation from all types of academic institutions and one representative from the Professional Enhancement Committee to develop model statements appropriate to librarians.

Received the Certification Task Force report, thanked and dismissed its members, and went on record expressing interest in participating with ALA in the development of a postMLS recognition program should it decide to develop one.

\section{Standards and guidelines Voted to adopt the ACRL "Guidelines for Un- dergraduate Libraries."}

Voted to approve the revised "Guidelines for Instruction Programs."

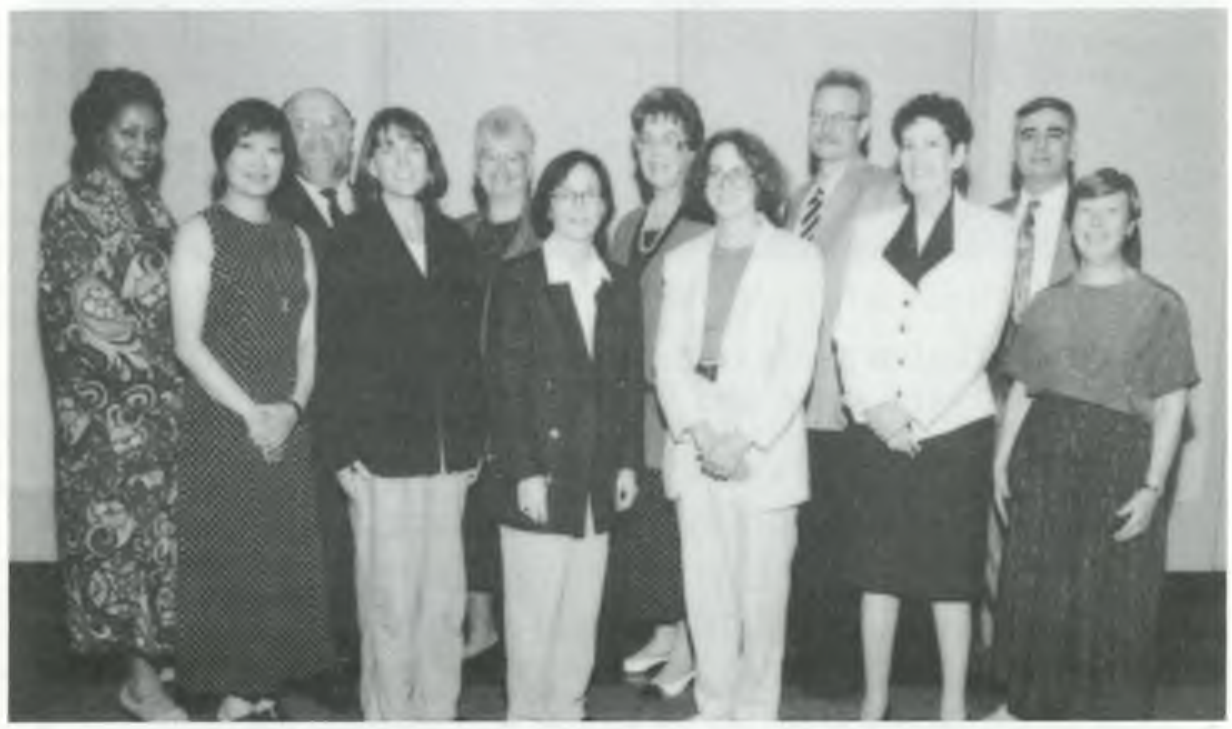

ACRL Board 96-97 (1 to r): Althea Jenkins, Linda Muroi, Bernard Fradkin, Frances Maloy, Mary Reichel, Victoria Montavon, Patricia Senn Breivik, Carol Pfeiffer, W. Lee Hisle, Jill Fatzer, William Miller, and Maxine Reneker. Not shown: Ray English. 


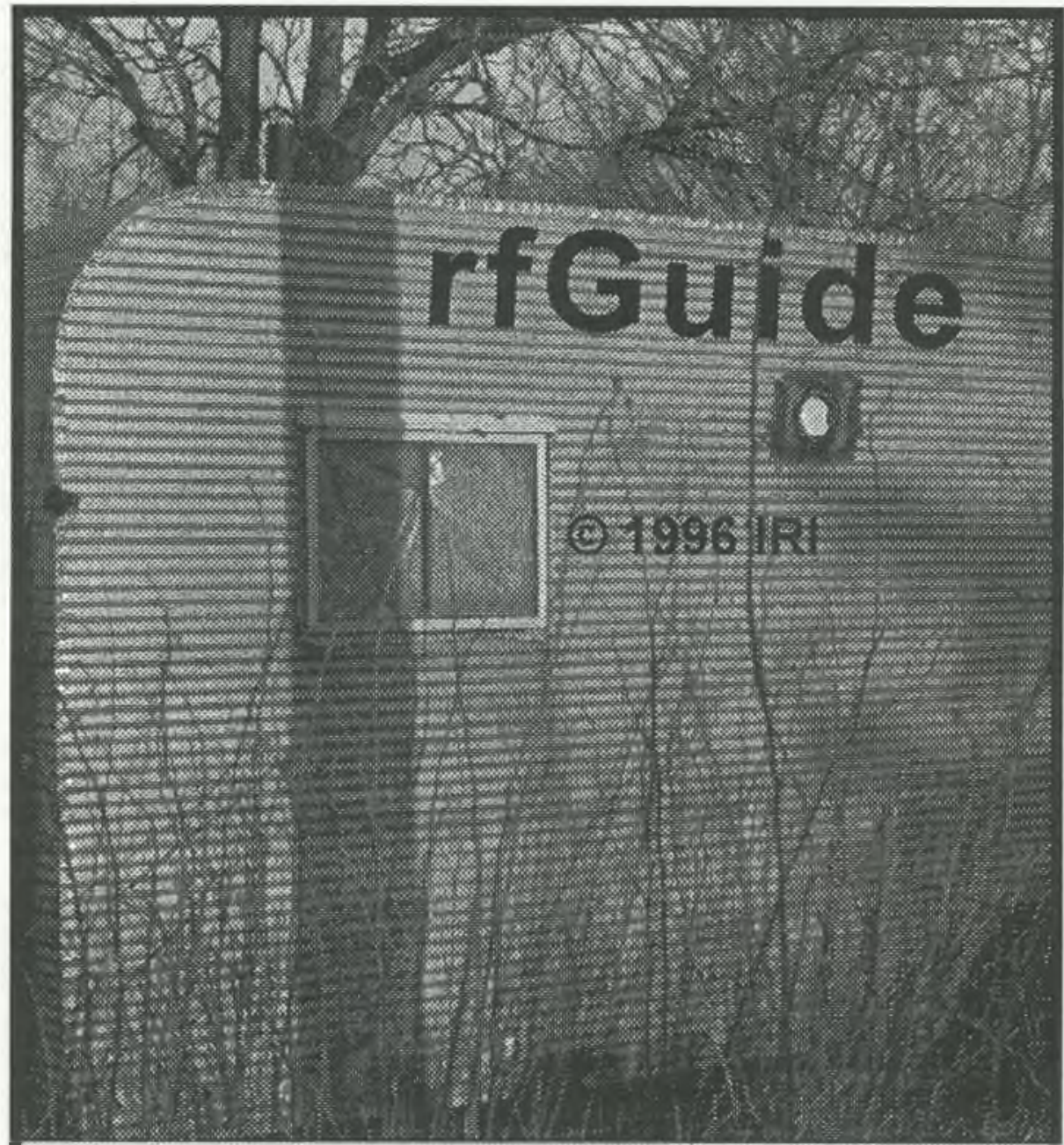

rfguide - (pronounced rough guide) n. a database program that was designed for the librarian who uses a pc with Microsoft Windows $®$ and Microsoft Word®; another way of doing reference guides that makes life easier and even more interesting.

To order rfGuide write us at IRI, 314 South Third St., St. Peter, MN 56082 or call (800) 7.64-8697 or (507) 931-4083.

For more information see our web site: http://www.ic.mankato.mn.us/web/iri. Email: fister@gac.edu to contact the librarian who instigated this thing. 